\title{
PERILAKU CERDIK LANSIA DIABETES MELITUS YANG MENDAPATKAN DUKUNGAN KELUARGA
}

\author{
Mujito', Meilysa Indah Wahyu Ningsih ${ }^{2}$, \\ 1,2 Program Studi D3 Keperawatan Blitar Politeknik Kesehatan Kemenkes Malang \\ Email: cak.sidik@yahoo.co.id
}

\begin{abstract}
Abstrak
Perilaku cerdik merupakan salah satu upaya dalam pencegahan penyakit Diabetes Melitus merupakan singkatan dari cek kesehatan secara berkala, enyahkan asap rokok, rajin olahraga, diet seimbang, istirahat cukup, dan kelola stres. Upaya pencegahan ini juga tidak lepas dari peran serta dukungan keluarga. Diabetes Melitus merupakan penyakit tidak menular yang menjadi penyebab kematian terbanyak serta penyakit ini lebih rentan diderita pada orang lanjut usia. Penelitian ini bertujuan untuk mengetahui dukungan keluarga terhadap perilaku cerdik pada lansia pengidap Diabetes Melitus. Metode penelitian ini menggunakan studi kasus deskriptif kualitatif dengan melakukan wawancara terstruktur kepada lima keluarga yang menjadi pertisipan di wilayah Kelurahan Bendo yang memeriksakan kesehatan di Puskesmas Kepanjenkidul Kota Blitar. Hasil penelitian tentang dukungan keluarga terhadap perilaku cerdik, yaitu memberikan dukungan penilaian berupa mengingatkan atau memotivasi lansia agar menerapkan perilaku cerdik, memberikan dukungan instrumental berupa bantuan nyata, memberikan dukungan informasional berupa memberikan sedikit pengetahuan tentang perawatan lansia pengidap Diabetes Melitus, serta dukungan emosional berupa kasih sayang dan perhatian. Namun masih ada hal-hal yang perlu diperhatikan seperti kurangnya dukungan penilaian atau dorongan untuk berperilaku cerdik. Diharapkan tenaga kesehatan dapat memberikan dukungan dan dorongan kepada keluarga untuk selalu memperhatikan kebutuhan lansia pengidap Diabetes Melitus dengan cara menerapkan perilaku cerdik melalui edukasi kesehatan.
\end{abstract}

Kata kunci: Diabetes Melitus, Dukungan Keluarga, Lansia, Perilaku Cerdik.

\begin{abstract}
Cerdik Behavior of Elderly People with Diabetes Mellitus Who Get Family Support. Cerdik behavior is one of the efforts to prevent diabetes mellitus is abbreviation of periodic health checks, eliminating cigarette smoke, diligent exercise, a balanced diet, adequate rest, and managing stress. Prevention efforts are also inseparable from the role of family support. Diabetes Mellitus is a non-communicable disease which is the leading cause of death and this disease is more susceptible to the elderly. This study aims to determine family support for cerdik behavior in elderly people with Diabetes Mellitus. This research method used a descriptive qualitative case study by conducting structured interviews with five families who were participants in the Bendo Sub-district area who had their health checked at the Kepanjenkidul Health Center in Blitar City. The results of the study on family support for cerdik behavior, namely providing assessment support in the form of reminding or motivating the elderly to apply cerdik behavior, providing instrumental support in the form of real assistance, providing informational support in the form of providing a little knowledge about the care of elderly people with diabetes mellitus, and emotional support in the form of love and attention. But there are still things that need attention such as lack of assessment support or encouragement to behave cerdik. It is expected that health workers can provide support and encouragement to the family to always pay attention to the needs of elderly people with Diabetes Mellitus by applying cerdik behavior through health education.
\end{abstract}

Keywords: Cerdik Behavior. Diabetes Mellitus, Elderly, Family Support. 


\section{Pendahuluan}

Diabetes merupakan kondisi kronis yang paling mempengaruhi lansia, karena ketika seseorang menjadi tua kadar glukosa darah di dalam tubuh akan berubah. Batas normal pada lansia, yaitu 2 jam setelah makan kadar glukosa darah adalah 140 sampai $200 \mathrm{mg} / \mathrm{dL}$. Sedangkan kadar glukosa darah puasa kurang dari 140 $\mathrm{mg} / \mathrm{dL}$ untuk yang bisa diterima oleh lansia.

Sustainable Development Goals (SDGs) menetapkan indikator untuk mengurangi angka kematian prematur dari Penyakit Tidak Menular (PTM) salah satunya Diabetes sebanyak sepertiga pada tahun 2030. Menteri kesehatan menghimbau masyarakat untuk melakukan aksi CERDIK. Hal ini dilakukan pemerintah untuk mengurangi angka kejadian Diabetes Melitus di Indonesia yang dari tahun ketahun mengalami peningkatan. Dengan dilakukannya upayaupaya preventif dan promotif yang telah dicanangkan oleh pemerintah dapat meningkatkan kualitas hidup dan kesejahteraan masyarakat.

Proporsi Diabetes Melitus pada usia 15 tahun ke atas sesuai hasil Riskesdas tahun 2007 sebesar 5,7\% dan pada tahun 2013 menjadi sebesar 6,9\% dengan yang telah terdiagnosa sebelumnya sebesar $30,4 \%$ dan yang belum terdiagnosa sebelumnya sebesar 69,6\%. Jika estimasi jumlah penduduk Indonesia usia 15 tahun ke atas pada tahun 2013 adalah 176.689.336 jiwa, maka dapat diperkirakan jumlah absolut penderita Diabetes Melitus adalah sekitar 12.191.564 jiwa; telah terdiagnosa 3.706 .236 jiwa; belum terdiagnosa 8.485.329 jiwa. Pengidap Diabetes Melitus pada lansia sesuai hasil Riskesdas tahun 2013 sebesar 4,8\% atau setara dengan 894.075,44 jiwa pada kelompok umur 65-74 tahun dan 3,5\% atau setara dengan 650.471,675 jiwa pada kelompok umur 75 tahun ke atas.

Menurut Profil Kesehatan Kota Blitar Tahun 2014, Berdasarkan pengamatan penyakit yang terjadi di kota Blitar tahun 2013-2014 terjadi peningkatan jumlah penderita Diabetes Melitus dari 11.231 jiwa menjadi 12.071 jiwa dalam 1 tahun. Kejadian ini menandakan bahwa tingkat penderita Diabetes Melitus di kota blitar cukup banyak. Upaya meningkatkan pelayanan perawatan pada penderita Diabetes Melitus terutama pada lansia sangat memerlukan peran serta dan dukungan keluarga.

Menurut Departemen Kesehatan dalam sudiharto, (2007) keluarga adalah unit terkecil dari masyarakat yang terdiri atas kepala keluarga serta beberapa orang yang berkumpul dan tinggal di satu atap dalam keadaan saling ketergantungan. 
Keluarga sangat berperan aktif dalam memberikan beberapa bentuk dukungan. Menurut (Friedman, 2010) bentuk dukungan keluarga, yaitu dukungan penilaian, dukungan instrumental, dukungan informasional, dan dukungan emosional. Dukungan penilaian meliputi pertolongan pada individu untuk memahami kejadian depresi dengan baik dan juga sumber depresi dan strategi koping yang dapat digunakan dalam menghadapi stressor. Dukungan instrumental meliputi penyediaan dukungan jasmaniah seperti pelayanan, bantuan finansial dan material berupa bantuan nyata (instrumental support material support), suatu kondisi dimana benda atau jasa akan membantu memecahkan masalah praktis. Dukungan informasional meliputi jaringan komunikasi atau tanggungjawab bersama, termasuk di dalamnya memberi solusi dari masalah, memberikan nasehat, pengarahan, saran, atau umpan balik tentang apa yang dilakukan oleh seseorang. Dukungan emosional meliputi memberikan individu perasaan nyaman, merasa dicintai saat mengalami depresi, bantuan dalam bentuk semangat, empati, rasa percaya perhatian sehingga individu yang menerimanya merasa berharga. Beberapa dukungan keluarga tersebut dapat memberikan semangat seseorang untuk bergaya hidup sehat salah satunya dalam bentuk perilaku cerdik. Hal ini sesuai dengan yang dicanangkan Kementerian Kesehatan RI tahun 2013 tentang upaya pengelolaan lansia yang menderita Diabetes Melitus dengan cara menerapkan perilaku cerdik.

\section{Metode}

Penelitian yang digunakan dalam studi kasus ini menggunakan metode deskriptif kualitatif. Penelitian dilakukan di wilayah Kelurahan Bendo Kecamatan Kepanjenkidul Kota Blitar. Sedangkan waktu penelitian dilakukan pada bulan April 2019. Objek penelitian adalah dukungan keluarga terhadap perilaku cerdik. Subjek penelitian yang digunakan dalam studi kasus ini yaitu lima keluarga dari lansia yang menderita Diabetes Melitus. Teknik pengumpulan data menggunakan teknik wawancara dengan mendatangi ke setiap rumah partisipan.

\section{Hasil}

Hasil wawancara yang telah dilakukan kepada semua partisipan tentang dukungan keluarga terhadap perilaku cerdik pada lansia pengidap diabetes melitus. Dukungan tersebut diantaranya adalah dukungan penilaian, dukungan instrumental, dukungan informasional, dan 
dukungan emosional yang dikaitkan dengan perilaku cerdik, yaitu cek kesehatan secara berkala, enyahkan asap rokok, rajin olahraga, diet seimbang, istirahat cukup, dan kelola stres. Berikut adalah pemaparan dari wawancara yang didapatkan peneliti.

Tema 1: Dukungan penilaian keluarga tentang perilaku cerdik pada lansia Diabetes Melitus.

Cek kesehatan secara berkala. Dukungan penilaian seperti pujian atau dorongan yang diberikan keluarga kepada lansia pengidap diabetes melitus tentang cek kesehatan secara berkala merupakan salah satu upaya untuk mengetahui perkembangan penyakit yang di derita. Beberapa partisipan sudah memberikan dorongan untuk cek kesehatan secara berkala, yaitu 2 dari 5 partisipan telah memberikan dukungan motivasi dan pujiannya: “...ya iya mengingatkan waktunya cek, terus kalau makan manismanis bu nganu gulanya..” (P1). “...ya sudah disini tempat'e jadi sudah rutin sendiri..."(P5). Beberapa partisipan ada juga yang belum memberikan dukungannya tentang cek kesehatan secara rutin karena beberapa alasan. Berikut kutipan 3 dari 5 partisipan yang tidak memberikan dukunganya : “...selama dia drop ini ya mbak ya gak bisa kemana-mana memang saya gak saya cek kan soalnya kenapa saya kasian saya kan harus wira-wiri wira-wiri ya yang penting saya kasih nutrisi aja pagi susu anu itu lengkap ya jadi saya gak saya cek kan karena usianya sudah lanjut..."(P2)

“... nggih mak'e mawon dadose ki mboten ngantos sak umpami kulo yugo nggih mbak kulo dereng mak"e nek lansia ngoten mak'e pun bidal piyambak...”(P3. “...mboten mboten blas, nggih namung ibu'e tok..."(P4)

Enyahkan asap rokok. Dukungan dalam menghindari asap rokok juga penting serta keluarga mempunyai peran utama didalamnya. 2 dari 5 partisipan telah memberikan dukungan berupa pujian atau semangat yang diketahui dari kutipan berikut: “...sebenarnya saya sudah anu mbak karena dia itu ya belum sadar itu kan susah untuk nyadarkan, ya memberi saran ya kalau bisa di luar...”(P2). “...bapak'e ngrokok, ya diwehi saran..."(P3). Sedangkan 3 dari 5 partisipan yang tidak memberikan dukungan, diketahui dari kutipan berikut: “...ndak ada yang merokok mbak, ndak ada masalah...”(P1). “..enggak, gak ada 
yang merokok...(P4). “...tidak ada yang merokok disini, ndak pernah..."( P5)

Rajin olahraga. Dukungan penilaian supaya lansia rajin untuk olahraga merupakan sebuah motivasi yang diberikan keluarga untuk meningkatkan lansia menerapkan olahraga yang baik dalam pencegahan komplikasi diabetes. Dari 5 partisipan hanya 1 yang telah memberikan dukungannya: “...iya biasanya tak temeni..."(P1). Sedangkan 4 dari 5 partisipan tidak memberikan motivasi, berikut beberapa kutipan partisipan: “...ndak mbak kadang kalau saya longgar ya saya kan orangnya sibuk ya mbak kadang sama kakak saya dibawa keluar...”(P2). “...mboten mbak, saking mbah'e piyambak malah sing ngubernguber mbah'e...”( P3). “...mboten nate blas...”(P4). “...enggak, nganu bangun pagi wes jalan-jalan sendiri..."(P5)

Diet seimbang. Dukungan yang diberikan keluarga tentang diet seimbang sangat berpengaruh terhadap perkembangan diabetes yang diderita lansia, sehingga dalam merawat atau memberikan makanan harus diperhatikan bahkan harus dibedakan dari keluarga lainnya. Kondisi 2 dari 5 partisipan telah memberikan dukungannya terlihat dari kutipan berikut: “...ya kadang-kadang diingatkan, kalau mau makan hayoo jarene
diet...”(P1). “... iya kadang-kadang apa itu makannya ndak boleh banyak-banyak, minum manis boleh tapi gak misalnya pagi sudah minum sari kedelai siang lagi minum kolak itu kan gak boleh..."(P5). Sedangkan 3 dari 5 partisipan tidak memberikan motivasi untuk lansia. Dilihat dari kutipan berikut: “...tapi saya gak mau repot jadi apa adanya dimakan..."(P2). “...mboten mbak, ngih namung ngraosaken darah'e inggil cek trus mangke pados obat...”(P3. “...mboten ngasih motivasi..."(P4)

Istirahat cukup. Dukungan penilaian dalam bentuk dorongan untuk menerapkan istirahat yang cukup dari pendapat 5 partisipan tidak memberikan motivasi, berikut kutipan percakapan partisipan: “...enggak, pokok wes ket biyen ngunu subuh tangi...”(P1). “...ya istirahat sendiri mbak...(P2). “...ya nggih nganu mbak biasane mbak'e mawon sing ngertos...”(P3). “...mboten mbak...”(P4). “...mboten, penak tidur'e...”(P5)

Kelola stres. Dalam mengelola stres dukungan yang diberikan keluarga sangat berpengaruh terhadap lansia yang mengidap diabetes untuk mengurangi komplikasi yang berat. Kondisi 2 dari 5 partisipan sudah memberikan dorongannya, berikut kutipan yang menunjukkan dukungan penilaian: “...iya diajak jalan- 
jalan, nanti pulang'e beli martabak..."(P1).

“...iya sering pokok enek tontonan neng alun-alun sering dijak...(P3). Sedangkan 3 dari 5 partisipan tidak memberikan motivasi kepada lansia supaya tidak banyak pikiran atau stres, berikut kutipannya: “...enggak mbak...”(P2). “...mboten blas..”(P4. “...enggak enggak pernah..."( P5).

Tema 2 : Dukungan instrumental keluarga tentang perilaku cerdik pada lansia Diabetes Melitus.

Cek kesehatan secara berkala. Dukungan instrumental dalam keluarga berupa bantuan yang telah diberikan kepada lansia untuk membantu lansia dalam melakukan cek kesehatan secara berkala. Bantuan ini telah diberikan oleh partisipan kepada lansia, yaitu 3 dari 5 partisipan. Berikut pernyataaan partisipan: “...iya dibiayai untuk cek kesehatan dan di antar...”(P1). “...enggih diantar ke posyandu lansia...”(P3). “...saya cek sendiri pakai alat posyandu lansia dirumah..."(P5). Sedangkan 2 dari 5 partisipan tidak memberikan bantuan, berikut pernyataannya: “...dulu tak belikan mbak itu untuk cek gulanya, tapi sekarang saya gak lanjut... (P2. “...mboten, kalau ingin periksa ya kesana sendiri pulang ya sendiri tidak ada yang mengantar karena sibuk kerja semua..."(P4).
Enyahkan asap rokok. Dukungan bantuan yang di berikan dalam menghilangkan perilaku merokok atau asap dari orang lain, berikut dari pernyataan 1 partisipan: “...ya paling kalau merokok diluar biar asapnya tidak masuk..."(P2). Sedangkan 4 dari 5 partisipan tidak pernah memberikan bantuan secara nyata, pernyataan partisipan sebagai berikut: “...tidak ada yang merokok juga tidak ada keturunan merokok jadi tidak pernah memberikan bantuan apa-apa...”(P1). “...tidak ada mbak...”(P3). “...mboten nate...”(P4). “...gak ada yang merokok, jadi ya enggak...(P5).

Rajin olahraga. Beberapa partisipan telah memberikan bantuannya supaya lansia rajin berolahraga, yaitu 3 dari 5 partisipan yang diteliti, berikut pernyataan partisipan: “...biasanya saya temani jalanjalan..”(P1). “...kadang dibawa keluar untuk di dede ya ditunggu...”(P2). “...kemarin baru dibelikan terapi alas kaki buat olahraga..."(P3.). Sedangkan 2 dari 5 partisipan yang tidak memberikan bantuan, salah satu pernyataannya sebagai berikut: “...tidak pernah ditemani karena sudah dengan tetangga yang sama tuanya itu kan banyak...”(P5. “...ya ibunya sendiri senam dipuskesmas, kalau ke pasar ya sepedahan..."(P4). 
Diet seimbang. Bantuan dalam menerapkan diet seimbang untuk lansia pengidap diabetes sudah cukup baik diberikan, dari 5 partisipan terdapat 3 partisipan sudah peduli dengan makanan yang di konsumsi lansia pengidap diabetes, berikut pernyataan partisipan: “...di belikan buah-buahan dan selalu ada di kulkas ya belimbing ya selalu ada buah..”(P1). “... ya sekali-kali kalau ada uang dibelikan buah...”(P4). “...ya memasakkan sendiri, ibu dua hari sekali parut wortel, apel, tomat..."(P5). Sedangkan 2 dari 5 partisipan tidak memberikan bantuan apa-apa untuk konsumsi diet yang seimbang, berikut pernyataan partisipan: “...endak mbak kalau sekarang makan apa adanya... ”(P2). “...mboten mbak, emak masak piyambak..."(P3).

Istirahat cukup. Dalam memenuhi istirahat yang cukup bagi lansia, semua partisipan tidak memberikan bantuan apaapa karena berbagai alasan, berikut pernyataan partisipan: “...enggak ada masalah tidur...”(P1). “...gak ngasih bantuan mbak...”(P2. “...mboten nate memberikan bantuan apa-apa mbak...”(P3). “...mboten mbak...”(P4). “...enggak mbak, sudah tidak berpengaruh soal'e ibu tidur'e nyenyak, gampang..."(P5).
Kelola stres. Bantuan untuk mengelola stress telah diberikan oleh 4 dari 5 partisipan. Berikut pernyataan partisipan: “...ya diajak jalan-jalan di belikan makanan...”(P1). “...ya kalau rewel ditunggu disampingnya...”(P2). “...iya diajak lihat tontonan..."(P3). “...hiburannya ngaji, nariah, kadangkadang kalau jauh ya diantar kalau dekat ya jalan kaki..."(P5). Sedangkan 1 partisipan tidak memberikan bantuan untuk mengelola stress, berikut pernyataannya: “...mboten blas mbak ya sudah situ sendiri..."(P4).

Tema 3: Dukungan informasional keluarga tentang perilaku cerdik pada lansia Diabetes Melitus

Cek kesehatan secara berkala. Peneliti menemukan 3 dari 5 partisipan memberikan informasi kepada lansia yang mengidap diabetes. Dukungan informasional dalam cek kesehatan secara berkala ini diketahui dari pernyataan berikut: “... sudah diberitahu kemarin juga beli buku tentang diabetes melitus untuk ibu...”(P1). “...iya mbak diberi tahu..”(P3). “...sudah, kalau posyandu juga sering diberi pengarahan kan..."(P5.) Sedangkan 2 dari 5 partisipan tidak memberikan informasi tentang cek kesehatan secara berkala untuk lansia pengidap diabetes. 
Berikut pernyataan partisipan: “...enggak mbak, dia tidak bisa merasakan jadi gak bisa ngasih informasi...”(P2). “...mboten nate ngasih tahu mbak, kalau ibunya ingin periksa ya berangkat sendiri..."(P4).

Enyahkan asap rokok. Pengetahuan keluarga tentang enyahkan asap rokok sudah diketahuinya dan terdapat 3 dari 5 partisipan yang mengatakan telah memberitahu lansia serta anggota keluarga lainnya untuk mengenyahkan asap rokok dengan pernyataan berikut: “... ya sudah diberi tahu...”(P2). “...sudah diberi tahu tapi tetap merokok bapaknya..."(P3). “...ya sudah, kalau orang yang menghirup dengan orang yang merokok langsung lebih bahaya yang menghirup disekitarnya..."(P5). Sedangkan 2 dari 5 partisipan terlihat tidak mengetahui pentingnya untuk mengenyahkan asap rokok dan terlihat acuh terhadap lingkungan. Berikut pernyataaan partisipan: “...enggak mbak, sudah ngerti sendiri...”(P1). “...saya enggak memberi tahu, sana ya sana, sini ya sini, dijaga sendiri-sendiri..."(P4).

Rajin olahraga. Rajin olahraga juga merupakan informasi penting untuk diberi tahu kepada lansia pengidap diabetes. Dari penelitian yang dilakukan semua partisipan tidak pernah memberikan nasehat, pengarahan, saran atau solusi kepada lansia untuk berolahraga. Pernyataaan pastisipan sebagai berikut: “...belum terlalu mengerti tentang olahraga yang baik gimana..."(P1). “...ibunya tidak bisa menerima jadi tidak...”(P2). “...dereng ngertos mbak kulo...”(P3). “...mboten mbak...(P4). “...belum pernah diberi tahu...”(P5).

Diet seimbang. Pengetahuan tentang diet yang seimbang untuk lansia pengidap diabetes merupakan informasi yang penting dalam menjaga kestabilan kadar gula di dalam darah. Peneliti mendapatkan 2 dari 5 partisipan telah memberikan informasi seperti pernyataan berikut: “...ya dikit-dikit diberi tahu gak boleh makan kacang...”(P3). “...kalau itu sudah, nasi yang bagus kan nasi kemarin dan yang sudah dingin tidak panas-panas..."(P5). Sedangkan 3 dari 5 partisipan tidak memberikan dukungan informasional tentang diet yang seimbang, terlihat dari kutipan berikut: “...belum terlalu paham tentang diet yang baik untuk diabet...”(P1 ). “...enggak pernah...”(P2). “...mboten mbak...”(P4.)

Istirahat cukup. Dukungan informasional yang telah diberikan dari 5 partisipan yang diteliti semua tidak pernah memberikan nasihat tentang istirahat yang cukup. Berikut pernyataan partisipan: “...belum tahu istirahat yang cukup gimana, karena ibunya juga mudah 
tidurnya...”(P1). “...ya ibunya ndak bisa menerima jadi endak...”(P2). “...dereng mbak...”(P3). “...mboten blas mbak...”(P4). “...enggak soalnya ibe'e tidur'e mudah..."(P5).

Kelola stres. Dari hasil wawancara yang dilakukan peneliti dari 5 partisipan hanya 1 yang memberikan dukungan informasional kepada lansia, seperti pernyataan berikut: “...ya diberi tahu jangan terlalu stres jangan kecapekan nanti gulanya naik..."(P1). Sedangkan 4 partisipan lainnya tidak memberikan dukungan informasional. Berikut pernyataan partisipan: “...tidak pernah mbak...”(P2). “...dereng nate...”(P3). “...mboten blas...”(P4). “...enggak mbak ya biasa aja ya mau ini ya terserah..."(P5)

Tema 4 : Dukungan emosional keluarga tentang perilaku cerdik pada lansia Diabetes Melitus

Dukungan emosional merupakan pemberian perasaan nyaman, merasa dicintai, rasa empati, rasa percaya serta perhatian untuk melakukan perilaku cek kesehatan, enyahkan asap rokok, rajin olahraga, diet seimbang, istirahat cukup dan kelola stres yang diberikan keluarga kepada lansia pengidap diabetes. Dan setelah dilakukan wawancara semua parisipan selalu memberikan dukungannya,
Berikut pernyataan partisipan: “...kalau perhatian ya selalu diberikan dan di ingatkan tentang kesehatannya..."(P1). “...ya iyalah mbak sebagai orang tua ya pasti lah ya walaupun kakak-kakak saya adik-adik saya jauh, kadang kalau ibu merasa kangen mesti rewel akhirnya ya saya panggil walaupun cuma satu malam tidur disini ataupun berapa jam disini tetap saya gilir...”(P2). “...enggih mbak, kalau obatnya habis ya diingatkan..."(P3). “...ya baik dikasih perhatian tetap sayang jenenge istri...”(P4). “...iya sering berkumpul, biasanya seminggu sekali anak-anaknya yang lain juga kesini kecuali yang jauh disana..."(P5).

\section{Pembahasan}

Peneliti menemukan partisipan yang memberikan dukungan penilaian tentang cek kesehatan secara berkala hanya 2 partisipan, enyahkan asap rokok hanya 2 partisipan, rajin olahraga hanya 1 partisipan, diet seimbang hanya 2 partisipan, istirahat cukup tidak ada yang memberikan dukungan, dan kelola stres hanya 2 partisipan. Para partisipan tidak memberikan dukungannya karena berbagai alasan salah satunya karena mereka terlalu sibuk dengan pekerjaan sehingga kurang memberikan dukungannya kepada lansia. Menurut (Harnilawati, 2013 dalam 
Nurwulan, 2017) didalam dukungan penilaian, individu mempunyai seseorang yang dapat diajak bicara tentang masalah mereka, terjadi melalui ekspresi pengharapan positif individu kepada individu lain, penyemangat, persetujuan terhadap ide-ide atau perasaan seseorang dan perbandingan positif seseorang dengan orang lain. Dari penjelasan tersebut dapat dikatakan bahwa partisipan kurang menjalankan perannya untuk memberikan semangat dan waktu luangnya untuk mendengarkan apa yang sedang dirasakan oleh lansia. Memberikan sebuah motivasi penyemangat dapat membuat lansia menjadi lebih baik terutama bagi kesehatannya, Jika keluarga memberikan dukungan untuk menerapkan perilaku cerdik diharapkan dapat meningkatkan kesehatan atau mencegah terjadikan komplikasi yang tidak diinginkan.

Dukungan instrumental yang diberikan keluarga kepada lansia pengidap Diabetes Melitus tentang cek kesehatan secara berkala sebanyak 3 partisipan, enyahkan asap rokok hanya 1 partisipan, rajin olahraga sebanyak 3 partisipan, diet seimbang sebanyak 3 partisipan, istirahat cukup tidak ada yang memberikan dukungan dan kelola stres sebanyak 4 partisipan. Partisipan telah memberikan dukungan ini berupa bantuan nyata seperti memberikan waktunya untuk menemani lansia, bantuan lain seperti memfasilitasi bahkan membiayai dalam proses berperilaku cerdik. Menurut (Harnilawati, 2013 dalam Nurwulan, 2017) dukungan instrumental merupakan bentuk bantuan secara nyata, seperti seseorang memberi atau meminjamkan uang, membantu pekerjaan sehari-hari, menyampaikan pesan, menyediakan transportasi, menjaga dan merawat saat sakit yang dapat membantu memecahkan masalah. Pernyataan tersebut dapat diartikan bahwa partisipan sudah dapat menyediakan bantuannya supaya kesehatan lansia menjadi lebih baik. Terbukti dari partisipan yang memberikan bantuan lebih banyak dalam berperilaku cerdik, kadar gula darah lansia dapat dikontrol sehingga kondisi masih dalam batas normal. Sedangkan berbeda dari partisipan yang kurang memberikan bantuannya, kondisi kadar gula darah lansia semakin tinggi bahkan. Jadi bantuan ini sangat perlu diterapkan didalam keluarga supaya tercipta kesejahteraan dan kesehatan yang baik bagi lansia pengidap diabetes melitus.

Dukungan informasional yang diberikan keluarga kepada lansia dalam perilaku cerdik, dimulai dari cek kesehatan secara berkala sebanyak 3 partisipan, enyahkan asap rokok sebanyak 3 partisipan, rajin olahraga tidak ada yang memberikan dukungan, diet seimbang hanya 2 
partisipan, istirahat cukup tidak ada yang memberikan dukungan, dan kelola stres hanya 1 partisipan. Partisipan memberikan informasi yang diketahuinya kepada lansia dengan tujuan lansia dapat mengerti dan menerapkan perilaku cerdik secara mandiri. Menurut (Harnilawati, 2013 dalam Nurwulan, 2017) dukungan informasional yaitu memberikan solusi dari masalah, memberikan nasehat, pengarahan, saran atau umpan balik tentang apa yang dilakukan oleh seseorang. Dari penjelasan tersebut, dapat dikatakan partisipan yang telah memberikan informasi atau membantu menemukan jalan keluar dari masalah yang sedang dihadapi dapat menjadikan lansia lebih peduli kepada dirinya sendiri sehingga kesehatan lansia menjadi terjamin dan meningkat.

$$
\text { Dukungan emosional yang }
$$
diberikan keluarga kepada lansia tentang perilaku cerdik. Dari 5 partisipan yang diteliti, semua partisipan sudah memberikan dukungan, yaitu partisipan memberikan perhatian dan kasih sayang kepada lansia sehingga lansia tidak merasa cemas atau stres. Menurut (Harnilawati, 2013 dalam Nurwulan, 2017) dukungan emosional merupakan suatu bentuk perasaan nyaman, merasa dicintai, empati, rasa percaya, perhatian sehingga individu yang menerimanya merasa berharga. Dari penjelasan tersebut dapat disimpulkan bahwa dukungan ini sangat berpengaruh dalam proses penyembuhan atau pencegahan suatu penyakit yang diderita. Dukungan emosional ini menjadi sangat penting karena, jika dijalani dengan penuh keihklasan hati akan meningkatkan kesejahteraan serta kesehatan dalam keluarga. Peneliti mendapatkan semua partisipan telah melakukan perannya dengan baik di dalam menerapkan perilaku cerdik. Partisipan selalu menjaga dan merawat lansia pengidap diabetes semampu mereka serta dengan penuh kesabaran karena memang mereka adalah orang yang terdekat dan sangat dicintai.

\section{Kesimpulan}

Berdasarkan penelitian tentang dukungan keluarga terhadap perilaku cerdik pada lansia penderita Diabetes Melitus dengan jumlah partisipan 5 orang yang mempunyai karakteristik yang berbeda-beda, didapatkan bahwa dukungan penilaian yang diberikan keluarga kepada lansia pengidap Diabetes Melitus tentang cek kesehatan secara berkala hanya 2 partisipan, enyahkan asap rokok hanya 2 partisipan, rajin olahraga hanya 1 partisipan, diet seimbang hanya 2 partisipan, istirahat cukup tidak ada yang memberikan dukungan, dan kelola stres hanya 2 partisipan. 
Dukungan instrumental yang diberikan keluarga kepada lansia pengidap Diabetes Melitus tentang cek kesehatan secara berkala ada 3 partisipan, enyahkan asap rokok hanya 1 partisipan, rajin olahraga ada 3 partisipan, diet seimbang ada 3 partisipan, istirahat cukup tidak ada yang memberikan dukungannya, dan kelola stres ada 4 partisipan.

Dukungan informasional yang diberikan keluarga kepada lansia pengidap Diabetes Melitus tentang cek kesehatan secara berkala ada 3 partisipan, enyahkan asap rokok ada 3 partisipan, rajin olahraga tidak ada yang memberikan dukungan, diet seimbang hanya 2 partisipan, istirahat cukup tidak ada yang memberikan dukungan, dan kelola stres hanya 1 partisipan.

Serta dukungan emosional yang diberikan keluarga kepada lansia pengidap Diabetes Melitus tentang Perilaku Cerdik, semua partisipan sudah memberikan dukungannya. Terbukti dari dukungan yang sudah diberikan keluarga meliputi memberikan dorongan berupa pujian supaya lansia mempunyai keinginan sendiri berperilaku cerdik, memberikan bantuan nyata seperti memfasilitasi, membiayai bahkan menemani dalam proses berperilaku cerdik, memberikan informasi dan saran kepada lansia untuk menerapkan perilaku cerdik, serta memberikan dukungan emosional didalam keluarga sehingga lansia merasa diperhatikan dan tidak menimbulkan tekanan mental atau stres.

Penelitian ini membuktikan juga bahwa semakin besar dukungan yang diberikan semakin besar pula lansia dapat mempertahankan atau mengontrol kadar gula darahnya supaya tetap stabil. Diketahui dari partisipan pertama sangat peduli kepada lansia dan memberikan banyak dukungan sehingga hasil kadar gula darahnya stabil, sedangkan berbeda dengan partisipan keempat yang kurang memberikan dukungannya sehingga hasil kadar gula darah lansia sangat tinggi bahkan beresiko terjadi komplikasi lainnya. Dari penelitian yang dilakukan, peneliti dapat membuktikan bahwa dukungan keluarga untuk menerapkan perilaku cerdik kepada lansia pengidap Diabetes Melitus sangat berpengaruh kepada kadar gula darah dan kesehatan lansia serta juga sangat mendukung dalam proses penyembuhan atau pencegahan supaya tidak terjadi hal yang tidak diinginkan.

Dengan adanya penelitian ini, diharapkan keluarga dapat memberikan dukungannya untuk berperilaku hidup sehat, salah satunya berperilaku cerdik kepada lansia pengidap Diabetes Melitus sehingga dapat meningkatkan atau mempertahankan kesehatannya Bagi 
tenaga kesehatan sebaiknya dapat memberikan dukungan dan dorongan kepada keluarga untuk selalu memperhatikan kebutuhan lansia pengidap Diabetes Melitus dengan cara menerapkan perilaku cerdik melalui edukasi kesehatan.

\section{Referensi}

Adriana, Yayuk. (2017). Determinan Perilaku Cerdik Sebagai Upaya Pencegahan Penyakit Tidak Menular Pada Masyarakat Peserta Posbindu PTM. Tesis tidak diterbitkan. Jember: Universitas Jember.

Depkes.go.id. (2016). Menkes: Mari Kita

Cegah Diabetes dengan Cerdik, (http://www.depkes.go.id/article/vi ew/16040700002/menkes-marikita-cegah-diabetes-dengancerdik.html), diakses 16 Oktober 2018.

Dinas Kesehatan. (2015). Profil Kesehatan Kota Blitar Tahun 2014. Blitar: Dinas Kesehatan Kota Blitar.

Dinas Kesehatan. (2017). Rencana Kerja Dinas Kesehatan Kota Blitar Tahun 2018. Blitar: Pemerintah Kota Dinas Kesehatan.

Friedman, M. (2010). Keperawatan Keluarga Teori dan Praktik. Jakarta: EGC.
Nuraisyah, F, Hari K, Theodola B. (2015). Dukungan Keluarga dan Kualitas Hidup Pasien Diabetes Mellitus. Yogyakarta: UGM.

Pusat Data dan Informasi. (2014). Situasi dan Analisis Diabetes. Jakarta: Kementerian Kesehatan RI.

Rudianto, A， dkk. (2015). Konsensus Pengolahan dan Pencegahan Diabetes Melitus Tipe 2 di Indonesia 2015. Jakarta: PB PARKENI.

Sudiharto. (2007). Asuhan Keperawatan Keluarga Dengan Pendekatan Keperawatan Transkultural. Jakarta: EGC.

Yusriani, Khidri, A. (2018). Buku Ajar Promosi Kesehatan dan Pemberdayaan Masyarakat. Ponorogo: FORIKES. 